DOI: https://doi.org/10.31933/dijemss.v2i3

Received: $2^{\text {nd }}$ January 2021, Revised: $9^{\text {th }}$ February 2021, Publish: $12^{\text {th }}$ February 2021

\begin{tabular}{|c|c|c|}
\hline DINASTI & $\begin{array}{l}\text { DIJEMSS } \\
\text { DINASTI INTERNATIONAL JOURNAL } \\
\text { OF EDUCATION MANAGEMENT AND } \\
\text { SOCIAL SCIENCE }\end{array}$ & $\begin{array}{r}\text { https://dinastipub.org/DIJEMSS } \\
\text { editor@dinastipub.org } \\
08117401455 \text { (1) }\end{array}$ \\
\hline
\end{tabular}

\title{
THE ROLE OF VISIONARY LEADERSHIP IN QUALITY CULTURE DEVELOPMENT THROUGH THE IMPLEMENTATION OF INTERNAL QUALITY ASSURANCE SYSTEM AS A MEDIATION (AN EMPIRICAL STUDY IN INDONESIAN PRIVATE HIGHER EDUCATION)
}

\begin{abstract}
Anik Herminingsih ${ }^{1}$
${ }^{1)}$ Management Programme Faculty of Economy and Bussiness, Universitas Mercu Buana, Indonesia, anik_herminingsih@ mercubuana.ac.id

Corresponding Author: Anik Herminingsih

Abstract: The government has responsibilities towards higher education qualities in Indonesia through The Ministry of Research, Technology, and Higher Education or Kemenristekdikti. The increasing global competition makes higher education in Indonesia follow a higher education trend called the implementation of a quality assurance system or SPMI. Directorate General of Learning and Student Affairs, in order to realize Kemenristekdikti's vision, has established a development program of SPMI 2015-2019 that aims to make a quality culture in Indonesia's higher education. 100 respondents involved as a proportionally determined research sample. Data analyzed by the explanatory approach using structural equation modeling or SEM and processed with the AMOS program. This research is expected to give a contribution to improving the growth of quality culture in higher education.
\end{abstract}

Keywords: quality culture, visionary leadership, quality assurance, structural equation model.

\section{INTRODUCTION}

The government has responded to organizing higher education governance by issuing binding regulations and laws that have consequences related to the legality of higher education. The Ministry of Research, Technology, and Higher Education or Kemristekdikti have visions about the quality of higher education: To realize quality higher education, science, and technology capabilities, and innovation to support the nation's competitiveness. In order to realize the vision, the Directorate General of Learning and Student Affairs has been established SPMI 2015 - 2019 development plan with the aim to establish a quality culture of higher education in Indonesia. Implementation of Internal Quality Assurance System (SPMI) in all higher education in Indonesia need to be encouraged and scouted by involving higher education 
that has been implemented SPMI well through college foster program or Program Asuh Perguruan Tinggi Unggul (Program PT Asuh). The purpose of PT Asuh program are 1) To encourage institutionalized internal quality assurance 2) To encourage the functioning of internal quality assurance system in a sustainable manner 3) To moderate the realization of quality culture and 4) To increase the number of study program that receive quality service.

According to Goetsch and Davis (2002) quality culture is an organizational value system that produces a safe environment for the formation and improvement of quality continuously. Malhi (2013) said that quality culture is a shared value system, beliefs, and norms that focused on customer satisfaction and continue to improve product and service quality. Schein in Herminingsih (2015) stated that organizational culture is an accumulation of joint learning from certain groups, involving behavioral, emotional, and cognitive elements from the total psychological function of group members. Once the organizational culture is formed, it will be hard to change. Organizational culture elements such as artifacts trust values and basic assumptions are dynamic. Implementation of SPMI that run consistently and continuously will be able to create a quality culture. This was proven by the study about quality assurance by Hsu (2017) stating that the implementation of quality assurance in Taiwan has brought a change in higher education management and improves lecturer's professionalism. Meanwhile, Vettoriet al. (2017) found that implementation of a quality assurance system has brought improvements in organizational communication, information system, quality culture, transparency, also the more obvious roles and responsibilities.

Based on Malhi (2013) dimensions of quality culture consist of 1) Focus on the customer, 2) Employee involvement and empowerment, 3) Open and honest communication, 4) Problems solving and decision making based on facts, 5) Continues improvement as a way of life, 6) Teamwork in the organization, 7) Process management, and 8) Quality-based rewards and recognition. It can be concluded that quality culture has the characteristic to always make improvement continuously, honesty and involvement, also employee empowerment. According to a study of Herminingsih and Ghozali (2014), the dominant culture is a hierarchical culture where higher education activities based on strict rules and lack of lecture and employee involvement in decision making.

The implementation of the Internal Quality Assurance System (SPMI) that aims to develop quality culture can be seen as an organizational culture transformational effort where leadership has the most important role. Even Schein in Herminingsih (2015) said that leadership and organizational culture like two sides of a coin. This is supported by Daft (2002) that said the leadership role is a relationship builder and values former in the organization. The importance of leadership in building organizational culture is supported by previous research by Herminingsih (2011), Klein et al. (2013), Gholamzadeha et al. (2014), also Sürücü1 and Yeşilada (2017). Those researches conclude that transformational leadership has an important role in organizational culture, especially in a leadership vision dimension.

Kotter and Hesket in Magnúsdóttir (2018) stated that most organization that makes a change ( 70 percent) is failed due to various factors. After that they suggested 8 steps to make the successful organizational transformation. Those stages need leadership that be able to 
communicate vision well and invite members of the organization to realize the organization's vision.

Research about the study of leadership influence towards higher education quality assurance has not yet found by the researcher. The existing studies are theoretical studies about leadership roles and higher education quality assurance. However, at this time there was enough research about the importance of leadership in the implementation of quality assurance system in the company, for example, previous research by Nga et al. (2015), Alharbi and Yussoff (2012), Iqbal and Iqbal (2011), also Campos et al. (2014). Some research shows the importance of leadership vision in leading change so that Kahn (2002) and Nanus (1992) deliver the concept of visionary leadership required to change an organization.

Based on the explanation above, this research will analyze the influence of visionary leadership towards SPMI implementation and the influence on quality culture formation of higher education. The comparison is applied towards five universities that are involved in Program Asuh Perguruan Tinggi Unggul 2017 and 2018. Research location selection based on the consideration that the researcher is a facilitator on the implementation of SPMI in the foster university, it has to be ensured that the implementation process has proceeded according to the regulation.

Formulations of the problems that will be studied in this research are: 1) Does visionary leadership affect the quality culture of higher education? 2) Does visionary leadership affect the implementation of higher education quality assurance system? 3? Does the implementation of the internal quality assurance system of higher education affect the quality culture of higher education?

\section{Purpose and Contribution of the Research}

This research aims to study and analyze: 1) How stakeholder perception towards higher education leadership and how SPMI implementation in each higher education. 2) To analyze visionary leadership influence towards quality culture of foster university. 3) To analyze visionary leadership influence towards SPMI implementation in higher education. And 4) To analyze SPMI implementation influence towards quality culture of higher education.

This research is expected to be guidance for higher education leader in determine evaluation of SPMI implementation in higher education. After they understand about SPMI and feel the urgency from SPMI implementation, higher education leader will be able to continue to the next step of change. However, if the understanding has not yet happened and SPMI implementation is not yet important, the effort should be stronger in order to make SPMI important. For authorized agency, this research can be the feedback of SPMI implementation of higher education in Indonesia.

Contribution of science development produced by this research is the availability of empirical study of quality assurance implementation and cultural quality. The application of 
quality assurance in higher education is a problem that should always be studied considering quality assurance applied first in manufacturing.

\section{LITERATURE REVIEW Internal Quality Assurance System (SPMI) and Higher Education Quality}

Quality is a concept that was born from manufacture management and then applied on higher education field. Quality has definition as conformity between performances with standard specification of a product or service that has been set by producers (Sudha, 2013). According to Standards and Guidelines for Quality Assurance in the European Higher Education Area (ESG), internal quality assurance system is one of the three pillars of higher education quality assurance system that consist of: 1) Internal quality assurance, 2) External quality assurance, and 3) Quality assurance institution. Internal and external quality assurance process completes each other and both of that are needed to achieve cultural quality in higher education system and in each higher education institution. This research will focus on SPMI and as implemented by Hsu (2017) and Standards and Guidelines for Quality Assurance in the European Higher Education Area (ESG), it consist of 5 steps: planning, implementation, evaluation, control and improvement. The five steps are a cycle that runs continuously as continual improvement.

\section{Quality Culture of Higher Education}

According to Schein in Herminingsih (2012) organizational culture is basic assumption pattern shared by a group of people where the assumption is a way to perceive, think and express feelings in relation to organizational issues. Organizational culture elements can be divided into visible element and invisible element. The deepest and invisible cultural element is basic assumptions. This element will affect organizational values and organizational values will affect artifact and human creation like habits in the organization. The influence direction is alternating, where the artifact, creation, and habits also affect organizational values. It will affect basic organizational assumption indirectly.

Quality culture of higher education can be interpreted as higher education culture that refers to quality of higher education. In the provisions concerning SPMI, quality culture is mindset, attitude patterns, and behavioral patterns according to SPMI. Quality culture, according to Malhi (2013) is shared values system, belief and norms focused on customer satisfaction and keep improving products and services quality. In an organization with quality culture, quality is planted almost in every organizational life aspect, including recruitment and promotion, employee orientation and ongoing training, compensation, management style, decision-making, organizational structure, working process and office layout.

Core values and belief on quality culture according to Malhi 92013) are: 1) Focus on customer; considering the quality is defined and rated by customer. 2) Employee involvement and empowerment where the employee empowered to serve customer well and belief that they have power to accomplish something. 3) Open and honest communication, the employee afraid of retribution for their honesty. 4) Problem-solving and decision-taking based on facts and either fact or data are reliable. 5) Continuous improvement as a way of life. 6) Teamwork in all 
organization, close cooperation between manager and employee and interdepartmental. 7) Process management by building quality into work process. 8) Rewards and recognitions are based on achievements of quality objective and demonstration of appropriate behavior.

Powel in Njiro (2016) present seven important elements that shows quality culture: 1) Consistency, 2) Benefit principles, 3) Learning environment, 4) Honesty, 5) Utilitarian, 6) Respects or rewards, 7) Empowerment that explores employee creativity.

\section{Leadership Roles on Organizational Culture Formation}

Brown (1998 : 743) said that the leader deliver culture through what they say and what they do. Schein (2004: 300-301) express leader's role in organizational culture where the leader have the biggest potential in instilling culture and strengthen culture with mechanism: 1) Attention, 2) Reaction to the crisis, 3) Role modeling, 4) Reward allocation, and 5)Selection criteria and employee's dismissal. Explanation about leadership role are: 1) Attention, where the leader in carrying out their leadership will communicate priorities, values, their attention by asking, giving opinion, praising, and expressing criticism. For example, leader who scolds a subordinate because they do not know problem that happens in their work unit, will have strong effect in communicating values and attention. Leaders who are not responding to something mean that it is not important. 2) Reaction to Criticism is a potential for employee to learn values and assumptions. For example companies that faces serious financial difficulties but avoid work termination and make policy to make the employee works shorter hours, so the company can cut the salary. The leader communicate strongly that he keeps his employee's work and based on his behavior, the employee believe that their leader uphold cooperativeness value. 3) Role Modeling is where leaders communicate their values and expectations through their action. Especially actions that show special loyality, self sacrifice, and services more than assigned. A leader who make policy or procedure yet he do not give attention, the leader communicate a message that it is not important or unnecessary. 4) Reward Allocations are criteria used as basic to allocate rewards like salary increase or promotion. It communicates what the leader and organization rated. Formal recognition, ceremonial events, and informal praise communicate attention and priority of the leader. For example, companies in United States of America relatively using difference status symbols than Japanese company. That privileged can be special cafeteria and parking lot. 5) Selection Criteria and Employee Dismissal is where leaders can affect culture by recruiting people that have values, skills, or certain characteristics and promotes them to positions of power. Criteria and procedures used to issue or dismiss members from an organization communicate values and attention from the leader.

\section{Visionary Leadership}

Visionary leaders have competence in decision making and couching their subordinate in the process of vision accomplishment. In the context of nationality, leadership means that visionary leaders are a leader that has vision of nation improvement in the future. Kahn (2002) explains that visionary leader have ability, competence, and extra expertise that propose success in the future. According to Nanus (1992), there are four visionary leadership roles as their visionary leader's competence: 1) Direction determinant; A leader should be able to make sure 
subordination about target or purpose of the organization. 2) Change agent; visionary leader, in the context of environmental changes or community needs, should have ability to meet the interests of stakeholders. 3) As spokesperson: visionary leaders have to be confident and be able to express their organizational vision to people outside or inside organization. It is not only to make sure message delivered, but also to make sure that other people understand the meaning easily. 4) Coach; Effective visionary leader must be a good coach for their subordinates or other people. They should coordinate every activity in group and make everyone in group involved in group activities. According to four roles of visionary leadership, Nanus (1992) developed visionary leadership behavior measurement that consists of 4 dimensions.

\section{Organizational Culture Transformation}

Quality culture development through implementation of internal quality assurance system (SPMI) can be seen as organizational culture change process. As stated by Kotter and Heskett in Magnúsdóttir (2018), eight steps to achieve success in change or transformation are: 1) Increase Urgency, is the first step of the success of organizational change, where everyone in organization feel compelled to make change. 2) Build the Guiding team, is group formation that will be guide of changing process or called change agents that have adequate capability in doing a group approach or ability of implementation methods. 3) Get the Right Vision, is clear vision ownership and it has been translated into challenging strategy. 4) Communicating for Buy In, is communicating vision and strategy until good common understanding happens and can be accepted by all organizational members. Good vision must be communicated clearly and directed. 5) Empower Action, overcome effectively obstacles arise that can stabilize experience in managing experience and increase confidence. 6) Create Short Term Win, In general change cannot be achieved in a short time. Small milestone is important to give sign how far change process goes. 7) Don't Let Up, Do not stop and continue change process before vision accomplished. Continue to improve sense of urgency in order to keep change spirit on fire. Always show that change process still continue until the declared vision is accomplished. 8) Make Change Stick, Make sure that the change is embedded as company culture until the change really rooted to the bottom of organizational structure.

\section{Previous Study}

Studies about the influence of leadership towards implementation of quality assurance have been conducted by Nga et al. (2015), Alharbi and Yussoff (2012), Iqbal and Iqbal (2011), also by Camposet al. (2014). Those research produce a success leadership behavior in implementation of quality assurance is leadership that be able to articulate vision, honest communication and empowerment to organizational members.

Research by Hsu (2017) study about quality assurance development of higher education in Taiwan. The result of empirical research stated that implementation of quality assurance in Taiwan has brought change in higher education management and improving lecturer professionalism. Vettoriet al. (2017), according to qualitative and quantitative research in higher education in Austria, said that implementation of quality assurance has brought improvement in 
organizational communication, information system, quality culture, transparency, also clear roles and responsibilities

The importance of leadership role in building organizational culture is supported by other research by Herminingsih (2011), Klein et al. (2013), Gholamzadeha et al. (2014), also Sürücü1 and Yeşilada (2017). Those researches conclude that transformational leadership has the most powerful influence toward organizational culture, especially in leadership vision dimension.

\section{Research Framework and Hypothesis}

According to research problems, theoretical review, and previous study, we defined of research framework. There are three variables on research where quality culture is dependent variable (Y2), leadership variable as independent variable (X1), and SPMI as intervening variable (Y1). The hypothesis of this research are: 1) Visionary leadership affects the implementation of Internal Quality Assurance System in higher education. 2) Visionary leadership affects quality culture of higher education. 3) Implementation of Internal Quality Assurance System affects quality culture of higher education.

\section{RESEARCH METHOD}

The research use survey method and belongs to explanatory research that aims to explain the influence between variables by testing hypothesis. Variables determination is based on theoretical justification. Populations of the research are all lecturer and educational staff in foster college of Universitas Karimun, Universitas Muhammadiyah Kudus, and Universitas Mercu Buana. Each college will be taken proportionally until reached total sample of 100 employees.

Variables that have been used in the research consist of 3 variables. Those are visionary leadership (X) as exogenous variable, implementation of internal quality assurance system or SPMI (Y) as intervening variable, quality culture of higher education (Z) as endogenous variable. Endogenous variable is a variable affected by other variable, intervening variable is variable between affected by exogenous variable and affect endogenous variable, while exogenous variable is unaffected variable in model. All variables are arranged in a questionnaire that consists of dimension, then it described in indicators. Questionnaire is filled by self-rating, where respondent fill questionnaire based on perception of their self. Measurement scale uses Likert scale 1 to 5 .

Primary data collected by using self-report filling questionnaire by respondent. Questionnaire submission technique is directly delivered to the respondent, where this technique is better than sending questionnaire by post because it minimize interpretation difference between respondent and researcher. Data for model estimation use Structural Equation Modeling or SEM by using Analysis of Moment Structure or AMOS package program version 15. The researcher uses SEM because it can test relation between complex variables to obtain complete picture in whole model. According to Bohlen in Ghozali and Fuad (2005:3) SEM can also test simultaneously: 1) Structural model relation between construct and dependent construct, 2) 
Relationship related to measurement model that can be seen from loading value between indicator and construct (latent variable).

Conclusion and suggestion are taken based on data processing and discussion results. Those are the answer from research problems. The research is expected to give suggestion about right leadership behavior in SPMI implementation in order to build successful quality culture of higher education in Indonesia. The researcher hopes that this research gives contribution of science development in human resources management, especially about leadership.

\section{RESULT AND DISCUSSION Respondent Characteristics}

According to questionaire data, respondent characteristic data divided based on gender, age, level of education, and work year as we can see in Table 1. Table 1 shows that from all of respondents, the numbers of male and female employee are not much different. It means that employee recruitment is not based on gender but preferably based on ability. Respondent aged over 30 years old with frequency of $14,00 \%$ while age of over 40 years old dominated with frequency of $86,00 \%$. Employee aged less than 30 years old did not found in the data. It means that the employees are mature enough.

\section{Confirmatory Factor Analysis}

Confirmatory analysis is an evaluation towards validity of variable measurement model using loading factor criteria bigger than 0,5 .

Table 1. Validity and Reliability of Measuring Instruments

\begin{tabular}{lcccc}
\hline & Loading Factor & Validity & Variant Extract & Reliability \\
\hline Visionary Leadership & & & & \\
Direction Determinant & 0,888 & Valid & & Reliable \\
Change Agent & 0,891 & Valid & 0,834 & \\
Spokesman & 0,841 & Valid & & \\
Coach & 0,878 & Valid & & \\
& & & & \\
SPMI & 0,864 & Valid & & \\
Spmi Existence & 0,889 & Valid & 0,765 & \\
Spmi Standard & 0,510 & Valid & & \\
Spmi Implementation & & & & \\
& & & & \\
Quality Culture & 0,869 & Valid & & \\
Quality First & 0,816 & Valid & & \\
Stakeholder In & 0,741 & Valid & 0,766 & \\
Next Process & 0,653 & Valid & & \\
Speak with Data & 0,549 & Valid & & \\
Upstream Management & Souble \\
\hline
\end{tabular}

Source: Research Data Processed (2019) 
Reliability criteria applied by manual counting with minimal criteria of 0,6 . Confirmatory analysis result in Table 5.2 shows that all measurement is valid and reliable. Strongest dimension in measuring visionary leadership is change agent, considering that dimension has the highest loading factor score. Dimension from SPMI variable that has highest score is SPMI standard existence. It means that it is the most important thing in measuring SPMI implementation in higher education. Dimension of quality first is the most important dimension in measuring quality culture, considering that it has highest loading factor score among dimensions of quality culture measurement.

\section{Normality Test}

Data normality test is conducted by using skewness and kurtosis criteria, and kurtosis and Mahalanobis index. Univariately, it meets assumptions with index less than 2. However, in multivariate basis, values of kurtosis and skewness exceed standard value. According to Mahalanobis index values, p1 and p2 value is less than 0,05 , but the amount is less than 10 percent and data cannot be deleted.

\section{Evaluation of Goodness-of-fit Model}

Evaluation of Goodness of fit model conducted by using 6 criteria with cut-of value as we can see in Table 5.3, (Ferdinant, 2014). Value obtained from data processing with AMOS compared to cut-of value and concluded that from 6 criteria, there are 4 criteria shows good model while 2 criteria are marginal. From the evaluation result, model is worth to get further analysis.

Table 2. Goodness-of-fit Index

\begin{tabular}{cccc}
\hline Goodness-of-fit Index & Cut-of Value & Value & Evaluation \\
\hline CMIN/DF & $<=2,00$ & 1,65 & Good \\
GFI & $>=0,90$ & 0,898 & Marginal \\
AGFI & $>=0,90$ & 0,824 & Marginal \\
CFI & $>=0,90$ & 0,964 & Good \\
PCFI & $>0,50$ & 0,657 & Good \\
RMSEA & $0,03-0,08$ & 0,078 & Good \\
\hline
\end{tabular}

Source: Research Data Processed (2019)

\section{Hypothesis Test Result}

Hypothesis test conducted by using $\mathrm{P}$ value criteria of 0,05 . If $\mathrm{P}$ value is less than 0,005 , research hypothesis is accepted and if the value bigger than 0,05, hypothesis is rejected. Hypothesis test result, according to Table 5.4, show that all research accepted because: 1) Visionary leadership affect significantly towards quality culture, 2) Visionary leadership affect significantly towards SPMI implementation and 3) SPMI affect significantly towards quality culture. It means that visionary leadership affect significantly towards quality culture directly or through SPMI. 
Table 3. Hypothesis Test Result

\begin{tabular}{llrrrrl}
\hline & & Estimate & S.E. & C.R. & P & Explanation \\
\hline SPMI & $<---$ & Visionary Leadership & 0,366 & 0,102 & 3,583 & $* * *$ Hypothesis accepted \\
Quality Culture & $<--$ & Visionary Leadership & 0,382 & 0,084 & 4,533 & $* * *$ Hypothesis accepted \\
Quality Culture & $<---$ & SPMI & 0,507 & 0,096 & 5,287 & $* * *$ Hypothesis accepted \\
\hline
\end{tabular}

Source: research Data Processed Data (2019)

\section{Discussion}

\section{1) The Influence of Visionary Leadership towards the Implementation of SPMI}

Hypothesis test result show that visionary leadership affect significantly towards implementation of SPMI in higher education. It means that the higher leader's visionary level perceived, the better SPMI. The result support previous studies that said leadership role importance in quality assurance. The importance of leadership influence towards quality assurance implementation has been stated by the research of Nga et al. (2015), Alharbi and Yussoff (2012), Iqbal and Iqbal (2011), and Camposet al. (2014). Those researches produce a successful leadership behavior in the implementation of quality assurance that be able to articulate vision, honest communication and empowerment to organizational member.

The most important thing in dimension of visionary leadership is a leadership as change agent; visionary leader should have ability to meet the interest of stakeholder in the context of environmental changes or community needs. SPMI should be implemented in all higher education in Indonesia and have a role in higher education accreditation in order to be a demand of policy authority in organize and manage higher education system in Indonesia. SPMI can be seen as a demand to make a change in higher education governance in Indonesia. Respondent's assessment score in the three universities show that the most dominant dimension of visionary leadership is direction determinant on Universitas Karimun, dimension of leadership as coach in Universitas Muhammadiyah Kudus, and leader as spokesman in Universitas Mercu Buana. Dimension of leader as change agent should be improved in the three universities.

\section{2) The influence of Visionary Leadership towards Quality Culture}

The development of quality culture in higher education that becomes destination of SPMI implementation in Indonesia can be seen as cultural change effort of higher education. Schein (2005) said that organizational cultural change needs leadership roles. It is supported by Kotter (2012) that state the importance of leadership in organizational culture change. The important role of leadership in building organizational culture supported by previous research such as Herminingsih (2011), Klein et al. (2013), Gholamzadeha et al. (2014), and Sürücü1 and Yeşilada (2017). Those researches conclude that transformational leadership has strongest influence towards organizational culture, especially in dimension of leadership vision.

\section{3) The Influence of SPMI Implementation towards Quality Culture}

Schein (2005) stated that organizational culture consist of three elements. The deepest and invisible cultural element is basic assumption. The existence of this element described with vertical line to the top that affect organizational values. Organizational values affect artifact and 
human creation in organizational environment. Artifact is an observable element such as habits and artifact or human creation that has been done continuously also affect organizational values and basic assumption indirectly. Implementation of SPMI can be seen as habits planting in order to be a new culture, quality culture of higher education.

Empirical research that study about development of quality assurance in higher education has not been done much, especially in Indonesia. Research by Han (2017) study about development of higher education quality assurance in Taiwan. That empirical research states that implementation of quality assurance in Taiwan has brought change in higher education management and improving professionalism of the lecturer. According to quantitative and qualitative research of higher education in Austria, Vettoriet al. (2017) conclude that implementation of quality assurance system has brought improvement in organizational communication, information system, quality culture, transparency, also obvious roles and responsibilities

\section{CONCLUSION AND SUGGESTION Conclusion}

This research gives empirical evidence that visionary leadership affect significantly towards quality culture of higher education, visionary leadership affect significantly towards implementation of internal quality assurance system or SPMI, and internal assurance system affect significantly towards quality culture of higher education. In conclusion, visionary leadership affects quality culture directly and indirectly towards quality culture of higher education.

\section{Suggestion}

Considering that visionary leadership play important role in the development of quality culture, the researcher suggest leadership in higher education should improve visionary behavior. Descriptive statistics of respondent's answer from the three universities show that visionary leadership perceived well yet it needs improvement, especially in the dimension of leader as change agent. This research gives empirical evidence that implementation of internal quality assurance system or SPMI affect significantly towards quality culture of higher education. The data show that policy of quality assurance in higher education is a positive policy in creating quality culture of higher education. The important dimension is existence and implementation of SPMI standards. Descriptive statistic that is still relatively low compared to SPMI standard should be improved to make quality culture better.

\section{BIBLIOGRAPHY}

Alharbi, Mohammad and Rushami Zien Yusoff. 2012. Leadership Styles, and Their Relationship with Quality Management Practices in Public Horpital in Saudi Arabia .International Journal of Economics and Management Sciences Vol. 1, No. 10, 2012, pp. 59-67. 
Campos, Ana Cláudia, Júlio da Costa Mendes, João Albino Silva, and Patrícia Oom do Valle.2014. Critical success factors for a total quality culture: A structural model. Tourism \& Management Studies, 10(1), pp:13-20.

Gholamzadeha, Dariush, Azadeh Tahvildar Khazaneha and Manijeh Salimi Nabi. 2014. The impact of leadership styles on organizational culture in Mapsa company. Management Science Letters 4 (2014) 2161-2170.

Goetsch, David. L, Staanley B.Davis, 2002, Quality Management, Introduction to Total Quality Management for Production, processing, and services, New Jersey: Prentice Hall.

Herminingsih, Anik. 2015. Budaya Organisasi. Mercu Buana dan CV. Andi.Yogyakarta.

Herminingsih, Anik. 2011. Pengaruh Kepemimpinan Transformasional Terhadap Budaya Organisasi. Jurnal Ilmiah Ekonomi Manajemen dan Kewirausahaan “Optimal” Vol. 5, No.1, pp:22-37.

Herminingsih, Anik and Farida Ghozali. 2014. Organizational Culture Typology for Competitive Private University. Journal of Advanced Management Science Vol. 2, No. 4, PP:321-325.

Hsu, Yu-Ping. 2017. The Development and Impact of the Quality Assurance System on Higher Education in Taiwan. Thesis submitted for the degree of PhD at UCL Institute of Education.

Iqbal, Muhammad and Muhammad Zafar Iqbal. 2011. Educational Leadership for Managing Quality: Problems, Issues, and Ethical Behavior. International Journal of Humanities and Social Science Vol. 1 No. 14; October 2011,PP:165-169.

Klein, Andrew S , Joseph Wallis and Robert A. Cooke. 2013. The impact of leadership styles on organizational culture and $\square \mathrm{rm}$ effectiveness: An Empirical study. Journal of Management \& Organization / Volume 19 / Issue 03 / December 2013, pp 241 - 254.

Magnúsdóttir, Helga Kristín. 2018. Implementing Strategy Using the Kotter 8-Step Change Process: A Case Study in a Large Consultancy Firm in Iceland. Thesis of 30 ECTS credits submitted to the School of Science and Engineering at Reykjavík University.

Malhi, Ranjit Singh. 2013. Creating and Sustaining: A Quality Culture. Journal of Defense Management. Vol.12, No.3, pp:157-162.

Nga, Poh Kiat, Jian Ai Yeowb, Tee Suan Chinb, Kian Siong Jeea, and Pei Hua Chan. 2015. Leadership styles and their impacts on TQM practices in Malaysian manufacturing firms. Faculty of Engineering and Technology, Multimedia University, Jalan Ayer Keroh Lama, Bukit Beruang, 75450 Melaka, Malaysia. 
Sürücü1 , Lütfi and Tahir Yeşilada. 2017. The Impact of Leadership Styles on Organizational Culture. International Journal of Business and Management Invention. Vol. 6, No. 8, PP:31-39.

Vettori, Oliver, Karl Ledermüller, Christoph Schwarzl, Julia Höcher, and Julia Zeeh.2017.Developing a Quality Culture through Internal Quality Assurance Vienna University of Economics and Business, Austria.International Institute for Educational Planning 7-9 rue Eugène Delacroix, 75116 Paris, France 